\title{
Tingkat Gemeinschaft City Masyarakat pada Permukiman Nelayan Kedung Cowek
}

\author{
Angelina Rointan Naibaho dan Dian Rahmawati \\ Departemen Perencanaan Wilayah dan Kota, Fakultas Arsitektur Desain dan Perencanaan \\ Institut Teknologi Sepuluh Nopember \\ e-mail:d_rahmawati@urplan.its.ac.id
}

\begin{abstract}
Abstrak-Salah satu daerah di Surabaya yang turut mengalami perkembangan kota ialah Kelurahan Kedung Cowek, Kecamatan Bulak. Perkembangan kota di Kedung Cowek berimplikasi pada terdapatnya permukiman kumuh. Untuk memberantas permukiman kumuh, sebelumnya di Kelurahan Kedung Cowek telah dilaksanakan program Perbaikan Lingkungan Permukiman (PLP-BK) pada tahun 2016. Sementara di daerah penelitian masyarakat menunjukkan adanya ciri gemeinshcaft terlihat dari masyarakat nelayan yang homogen, kekerabatan yang tinggi serta kondisi sosial budaya masyarakat. Oleh karena itu penelitian ini bertujuan untuk mengetahui tingkat gemeisnhcaft city masyarakat nelayan di Kelurahan Kedung Cowek. Metode analisis yang digunakan ialah teknik analisa deskriptif kualitatif untuk menentukan deliniasi permukiman nelayan dan teknik analisa skoring untuk mengukur tingkat gemeinshcaft city masyarakat nelayan. Dari hasil studi ditemukan bahwa wilayah yang termasuk permukiman nelayan ialah RW 2 RT 1, RT 2, RT 3 dan RW 3 RT1, RT 2, RT 3. Hasil tingkat gemeinschaft city menunjukkan permukiman nelayan berada pada tingkat gemeinsncaft city tinggi dan sedang. Pengukuran tingkat gemeinshcaft citymasyarakat permukiman nelayan menggunakan variabel yang memiliki bobot berbeda.
\end{abstract}

Kata Kunci-deliniasi, gemeinshcaft city, permukiman nelayan

\section{PENDAHULUAN}

$\mathrm{S}_{\mathrm{p}}^{\mathrm{A}}$ ALAH satu daerah di Surabaya yang turut mengalami perkembangan kota ialah Kelurahan Kedung Cowek, Kecamatan Bulak. Perkembangan kota di Kedung Cowek berimplikasi pada terdapatnya permukiman kumuh. Permukiman kumuh ditunjukkan dari terdapat 342 unit bangunan yang tidak teratur, kepadatan bangunan sebesar 93 unit/ha dan terdapat 151 bangunan yang tidak sesuai persayaratan teknis. KDB di kawasan ini berkisar antara $90 \%$ - $100 \%$ dan GSB berkisar antara 0 - 1 meter. Jumlah bangunan yang memiliki izin surat mendirikan bangunan (IMB) berjumlah 142 unit bangunan sedangkan 317 lainnya tidak memiliki IMB. [1].

Pemerintah Kota Surabaya sudah mencoba mengurangi permukiman kumuh dengan menyelenggarakan program Program Penataan Lingkungan Berbasis Komunitas (PLP-BK) pada tahun 2016 dan membentuk Kelompok Swadaya Masyarakat (KSM) untuk memperbaiki permukiman kumuh. [2]. Namun program ini masih dirasa belum menangani masalah permukiman terlihat dari kondisi eksisting yang ada. Hal ini dikarenakan tidak ada peninjauan lebih lanjut dan swadaya masyarakat yang terbentuk merupakan buatan oleh pemerintah.
Pada penelitian sebelumnya dalam program GPO-BA (Global Partneship Output-Based Aid diketahui bahwa seharusnya implementasi pembangunan tidak boleh disama ratakan. [3]. Selain itu penelitian tentang pengukuran partisipasi masyarakat dalam program PLP-BK di Kelurahan Kedung Cowek diketahui bentuk partisipasi masyarakat hanya terlibat dalam tahap pelaksanaan dan tidak memiliki keberlanjutan karena masyarakat hanya diikutsertakan sosialisasi program permukiman kumuh.[4]. Kedua penelitian dan program PLP-BK berfokus pada perekrutan dan penilaian partisipasi masyarakat untuk bergabung dalam satu program tanpa memperhatikan potensi internal masyarakat tersebut.

Sementara, pada kelurahan ini terdapat 330 keluarga nelayan, kondisi sosial ekonomi yang berkembang di masyarakat baik serta memiliki kekerabatan yang cukup tinggi. Hal ini diindikasikan dari terdapatnya beberapa komunitas berupa kelompok nelayan.[5]. Adanya paguyuban atau kelompok nelayan serta kekerabatan yang terbentuk di Kelurahan Kedung Cowek ini mengindikasikan bahwa Kelurahan Kedung Cowek termasuk dalam tipikal kota gemeinschaft city. Gemeinshcaft city adalah kota atau area/bagian perkotaan yang memiliki karakter lokal dan nilainilai gemeinshcaft yang diindikasikan oleh hubungan/interaksi kekerabatan yang ada di wilauah tersebut dan terwuju dalam ekspresi keruangan yang intim dari masyarakatnya. [6].

Herlianto dalam Budiharjo (1984) menyatakan sifat homogen kampung yang masih bercirikan semangat "gemeinschaft", menguntungkan sekali dengan timbulnya spontanitas penduduk yang mengadakan swadaya perbaikan kampung. Sebetulnya kesadaran masyarakat setempat dalam memperbaiki lingkungan hidupnya, sudah cukup meluas, sehingga menghasilkan proyek-proyek swadaya, tetapi berhubung kurangnya perancangan dan terbatasnya dana maka perlu prakarsa perbaikan kampung dengan tujuan menaikan kualitas lingkungan hidup kampung, yang umumnya dihuni oleh masyarakat berpenghasilan rendah. [7]. Maka dari itu untuk melakukan perbaikan permukiman kumuh perlu terlebih dahulu dilakukan penelitian untuk mengetahui tingkat gemeinshcaft city masyarakat di Kelurahan Kedung Cowek yang bisa digunakan memperbaiki permukiman nelayan di Kelurahan Kedung Cowek.

\section{II. METODE PENELITIAN}

\subsection{Pendekatan Penelitian dan Variabel Penelitian}

Pendekatan yang digunakan dalam penelitian ini dengan menggunakan metode deskriptif kualitatif dan skoring. 
Deskriptif kualitatif digunakan untuk merumuskan kriteria. Sedangkan variabel yang digunakan dalam penelitian ini antara lain, 5 variabel untuk deliniasi permukiman nelayan dan 9 variabel gemeinshcaft city, yaitu aktivitas guyub, kelompok masyarakat, interaksi, kepercayaan, masalah, persepsi hunian, tingkat paritisipasi,kolaborasi, dan kemampuan menciptakan ruang.

\subsection{Pengumpulan Data}

Data-data dalam penelitian ini bersumber dari survei studi literatur sebagai data dasar yang diperkaya dengan observasi lapangan serta kuisioner untuk mengetahui tingkat gemeinshcaft city masyarakat nelayan di Kelurahan Kedung Cowek.

\subsection{Metode Analisis}

\section{A. Analisis Deliniasi Permukiman Nelayan Kedung Cowek}

Sebelum menganalisis tingkat gemeinshcaft city dari permukiman nelayan di Kelurahan Kedung Cowek, terlebih dahulu menemukan deliniasi permukiman nelayan. Teknik analisis yang digunakan menganalisis deliniasi permukiman nelayan ialah analisis dekriptif kualitatifdan menggunakan tools intersect software arcgis. Data yang digunakan untuk intersect ialah data primer melalui kuisioner yang ditanyakan kepada 30 orang sampel yang tersebar diseluruh RW dan RT yang ada di Kelurahan Kedung Cowek untuk mengetahui kondisi eksisting wilayah studi. Sebelum menemukan vaiabel yang digunakan untuk deliniasi terlebih dahulu mencari perumusan kriteria permukiman nelayan sebaagai berikut:

Tabel 1

Perumusan kriteria permukiman nelayan Kedung Cowek

\begin{tabular}{|c|c|c|c|}
\hline Variabel & Teori & Kondisi Eksisting & Pembahasan \\
\hline $\begin{array}{l}\text { Letak } \\
\text { permukiman } \\
\text { nelayan }\end{array}$ & $\begin{array}{l}\text { Menurut Budiharjo dalam } \\
\text { Ramdani B D (2013) } \\
\text { lingkungan permukiman } \\
\text { nelayan sangat berkaitan } \\
\text { erat dengan sumber } \\
\text { penangkapan ikan, daerah } \\
\text { distribusi hasil tangkapan, } \\
\text { daerah pantai, dimana } \\
\text { pantai mudah dijangkau } \\
\text { masyakarat nelayan }\end{array}$ & $\begin{array}{l}\text { Permukiman di wilayah studi } \\
\text { juga memiliki jarak yang dekat } \\
\text { dengan sumber penangkapan } \\
\text { ikan (laut) dan distribusi hasil } \\
\text { tangkapan, yakni di Sentra Ikan } \\
\text { Bulak. Rata-rata jarak dari } \\
\text { rumah nelayan ke bibir pantai } \\
\text { ialah } 0-50 \text { meter. (kategori } \\
\text { sangat dekat) }\end{array}$ & $\begin{array}{l}\text { Berdasarkan diskusi } \\
\text { pembahasan beberapa teori } \\
\text { dan kondisi eksisinng } \\
\text { tersebut, maka dapat ditarik } \\
\text { kesimpulan bahwa variabel } \\
\text { letak permukiman nelayan } \\
\text { pada wilayah studi relevan } \\
\text { digunakan untuk penentuan } \\
\text { deliniasi wilayah studi. }\end{array}$ \\
\hline $\begin{array}{l}\text { Kepadatan } \\
\text { bangunan } \\
\text { permukiman }\end{array}$ & $\begin{array}{l}\text { Menurut Suprijanto dalam } \\
\text { A'yun Q A (2017), } \\
\text { karakter fisik dari } \\
\text { permukiman nelayan ialah } \\
\text { jarak antar bangunan } \\
\text { cenderung rapat, } \\
\text { umumnya kumuh dan } \\
\text { belum tertata. }\end{array}$ & $\begin{array}{l}\text { Rumah-rumah nelayan yang ada } \\
\text { pada Kelurahan Kedung Cowek } \\
\text { saling berhimpita, tidak terdapat } \\
\text { jarak antara satu rumah dengan } \\
\text { rumah lainnya. Begitu juga } \\
\text { dengan pekarangan, } \\
\text { permukiman nelayan tidak } \\
\text { memiliki pekarangan rumah } \\
\text { seperti taman dan lainnya. }\end{array}$ & $\begin{array}{l}\text { Berdasarkan pembahasan } \\
\text { teori yang dipaparkan oleh } \\
\text { Suprijanto dalam A'yun QA } \\
\text { (2017), Lenski dalam Wardi } \\
\text { dkk (2014) dan kondisi } \\
\text { eksisting wilayah studi dapat } \\
\text { disimpulkan salah satu } \\
\text { karakter fisik permukiman } \\
\text { nelayan ialah kepadatan } \\
\text { bangunan tinggi. }\end{array}$ \\
\hline
\end{tabular}

\begin{tabular}{|c|c|c|c|}
\hline $\begin{array}{l}\text { Orientasi } \\
\text { bangunan } \\
\text { terhadap } \\
\text { kegiatan } \\
\text { perairan }\end{array}$ & $\begin{array}{l}\text { Menurut Suprijanto dalam } \\
\text { A'yun Q A (2017), } \\
\text { Orientasi bangunan } \\
\text { permukiman nelayan } \\
\text { semula menghadap ke } \\
\text { perairan sesuai orientasi } \\
\text { kegiatan, tetapi kini, } \\
\text { orientasi permukiman } \\
\text { lebih mempertimbangkan } \\
\text { aspek fungsional dan } \\
\text { aksesibilitas }\end{array}$ & $\begin{array}{l}\text { Kondisi permukiman nelayan di } \\
\text { wilayah studi sebagian besar } \\
\text { tidak menghadap ke perairan. } \\
\text { Hanya beberapa rumah saja } \\
\text { yang menghadap ke } \\
\text { perairan/laut yakni rumah } \\
\text { nelayan baru yang ada pada } \\
\text { jalan nambangan perak baru RW } \\
\text { 3RT } 3 \text {. }\end{array}$ & $\begin{array}{l}\text { Orientasi bangunan } \\
\text { menghadap ke perairan/laut } \\
\text { berdasarkan teori dan } \\
\text { kondisi eksisting tidak } \\
\text { ditemukam kesamaan. } \\
\text { Permukiman nelayan di } \\
\text { wilayah studi cenderung } \\
\text { tidak menghadap laut oleh } \\
\text { karena itu, untuk deliniasi } \\
\text { permukiman orientasi } \\
\text { menghadap laut ini kriteria } \\
\text { permukiman menghadap } \\
\text { laut kurang relevan }\end{array}$ \\
\hline $\begin{array}{l}\text { Kegiatan } \\
\text { sosial } \\
\text { masyarakat }\end{array}$ & 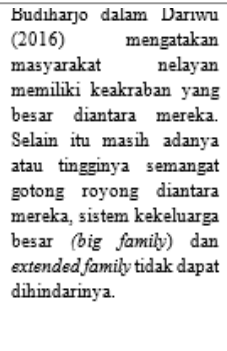 & $\begin{array}{l}\text { Masyarakat di Kelurahan } \\
\text { Kedung Cowek aktif dalam } \\
\text { melakukan kegiatan sosial } \\
\text { bersama baik berupa pengajian, } \\
\text { yasinan, tahlilan dan kegiatan } \\
\text { agama lainnya. }\end{array}$ & 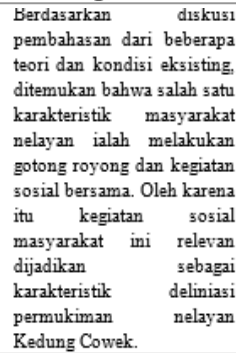 \\
\hline
\end{tabular}

\begin{tabular}{|c|c|c|c|}
\hline $\begin{array}{l}\text { Kegiatan } \\
\text { berorientasi } \\
\text { ke laut }\end{array}$ & $\begin{array}{l}\text { Menurut Budiharjo dalam } \\
\text { Dariwu } \\
\text { mengatakan } \quad \text { (2016) } \\
\text { karakter sosial budaya } \\
\text { masyarakat nelayan ialah } \\
\text { budaya yang beroritentasi } \\
\text { ke laut. }\end{array}$ & $\begin{array}{l}\text { Pada kondisi eksisting, kegiatan } \\
\text { masyarakat Kedung Cowek } \\
\text { yang beroriotentasi ke laut } \\
\text { berupa kegiatan ekonomi, mata } \\
\text { pencaharian sebagai nelayan } \\
\text { dan kegiatan gotong-royong } \\
\text { membersihkan laut. }\end{array}$ & $\begin{array}{l}\text { Menurut pemaparan } \\
\text { k } \\
\text { indiharjo dalam Dariwu } \\
\text { it } \\
\text { a berorientasi laut, pada } \\
\text { n } \\
\text { kondisi eksisting } \\
\text { g ditunjukkan dari kegiatan } \\
\text { ekonomi masyarakat } \\
\text { wilayah studi yang } \\
\text { berorientasi pada laut, yakni } \\
\text { nelayan. Dimana nelayan } \\
\text { menggantungkan ekonomi } \\
\text { nya pada hasil dan kegiatan } \\
\text { laut. }\end{array}$ \\
\hline Aksesibilitas & $\begin{array}{l}\text { Menurut Budiharjo dalam } \\
\text { Ramdani B D (2013) } \\
\text { lingkungan permukiman } \\
\text { nelayan sangat berkaitan } \\
\text { erat dengan sumber } \\
\text { penangkapan ikan, daerah } \\
\text { distribusi hasil tangkapan, } \\
\text { daerah pantai, dimana } \\
\text { pantai mudah dijangkau } \\
\text { masyakarat nelayan }\end{array}$ & $\begin{array}{l}\text { Berdasarkan citra satelit, } \\
\text { permukiman nelayan di } \\
\text { Kelurahan Kedung Cowek } \\
\text { tergolong dekat dengan laut. } \\
\text { Jarak permukiman sekitar 0- } \\
100 \text { meter ke bibir pantai. }\end{array}$ & $\begin{array}{l}\text { Berdasarkan pembahasan } \\
\text { teori dan kondsisi eksisting, } \\
\text { variabel aksesibilitas ini } \\
\text { relevan digunakan sebagai } \\
\text { kriteria deliniasi } \\
\text { permukiman nelayan. }\end{array}$ \\
\hline $\begin{array}{l}\text { Penduduk } \\
\text { bermata } \\
\text { pencaharian } \\
\text { nelayan }\end{array}$ & $\begin{array}{l}\text { Menurut Budiharjo dalam } \\
\text { Ramdani B D (2013), } \\
\text { permukiman nelayan } \\
\text { dihuni oleh penduduk } \\
\text { yang mempunyai kegiatan } \\
\text { sosial-ekonomi yang } \\
\text { berorientasi ke air atau } \\
\text { sebagai nelayan. }\end{array}$ & $\begin{array}{l}\text { Penduduk bermata pencaharian } \\
\text { nelayan di Kelurahan Kedung } \\
\text { Cowek berjumlah } 365 \text { orang. } \\
\text { Penduduk bermata pencaharian } \\
\text { nelayan berada pada RWl, RW } \\
2 \text { dan } R W 3 \text {. Terdapat sedikit } \\
\text { penduduk berprofesinelayan di } \\
\text { RW 1. Nelayan pada daerah ini } \\
\text { dibagi menjadi tiga nelayan } \\
\text { jaring, nelayan kerang dan } \\
\text { nelayan menyelam. }\end{array}$ & $\begin{array}{l}\text { Berdasarkan diskusi } \\
\text { pembahasan teori dan } \\
\text { kondisi eksisiting, maka } \\
\text { kriteria mata pencaharian } \\
\text { sebagai nelayan relevan } \\
\text { digunakan sebagai penentu } \\
\text { deliniasi permukiman } \\
\text { nelayan berdasarkan } \\
\text { kondisi nonfisik. }\end{array}$ \\
\hline $\begin{array}{l}\text { Penghasilan } \\
\text { masyarakat }\end{array}$ & $\begin{array}{l}\text { Menurut Budiharjo dalam } \\
\text { Ramdani B D (2013), rata- } \\
\text { rata penduduk nelayan } \\
\text { golongan ekonomi rendah. }\end{array}$ & $\begin{array}{l}\text { Menurut survei primer yang } \\
\text { dilakukan ke } 30 \text { responden, } \\
\text { didapatkan hasil bahwa rata-rata } \\
\text { penghasilan nelayan di } \\
\text { Kelurahan Kedung Cowek rata- } \\
\text { rata } 1,5 \text { juta }-3 \text { juta dan } \\
\text { beberapa mengungkapkan } \\
\text { pendapatan rata-rata } 1 \text { juta }-1,5 \\
\text { juta. }\end{array}$ & $\begin{array}{l}\text { Kesamaan yang dipaparkan } \\
\text { dalam kondisi eksising dan } \\
\text { teori menunjukkan bahwa } \\
\text { penghasiln nelayan dapat } \\
\text { juga digunakan sebagai salah } \\
\text { satu karakteristik penentu } \\
\text { permukiman nelayan. }\end{array}$ \\
\hline
\end{tabular}

Dengan mengombinasikan sumber informasi pada tabel diatas, maka dapat diketahui variabel yang relevan dan digunakan untuk deliniasi permukiman nelayan di Kelurahan Kedung Cowek, antara lain :

- Kriteria Fisik

1. Letak permukiman. Permukiman yang letak permukimannya dekat dengan laut, yakni berkisar 0100 meter ke laut

2. Akses permukiman ke laut . Dalam menjangkau laut, permukiman nelayan memiliki akses yang mudah dijangkau oleh masyarakat nelayan.

3. Kepadatan bangunan. Permukiman nelayan biasa memiliki kepadatan bangunan yang tinggi. Tidak ada jarak antara bangunan satu dan lainnya

- Kriteria Nonfisik

1. Kegiatan berorientasi laut. Permukiman yang kegiatan masyarakatnya berorientasi laut. Kegiatan ekonomi menangkap ikan di laut atau dengan kata lain berprofesi sebagai nelayan.

2. Kegiatan sosial masyarakat. Permukiman yang dihuni oleh masyarakat nelayan yang memiliki kegiatan sosial bersama sesama anggota warga dan kelompok nelayan, perkumpulan, guyub dan kegiatan sosial lainnya.

\section{B. Analisis Tingkat Gemeinshcaft City di Permukiman Nelayan}

Teknik analisis yang digunakan untuk mengukur tingkat gemeinshcaft city adalah metode skoring. Sebelumnya terdapat kuisioner yang membantu mendekripsikan karakteristik tiap variabel gemeinshcaft city yang diberikan pada masyarakat permukiman nelayan. Masing-masing variabel pada analisis ini menggunakan parameter yang diadaptasi dari pradinie 
(2018) dalam Paradigma dan Pengukuran Kota Guyub. Berikut merupakan pembobotannya :

Tabel 2.

Metode Pembobotan Gemeinshcaft City

\begin{tabular}{|c|c|c|c|}
\hline Indikator & Variabel & Kriteria & $\begin{array}{l}\text { Nilai } \\
\text { Bobot }\end{array}$ \\
\hline \multirow{12}{*}{$\begin{array}{c}\text { Nilai dan } \\
\text { Kepercayaan }\end{array}$} & \multirow{3}{*}{ Aktivitas guyub } & Tidak pernah ada aktivitas guyub & 0 \\
\hline & & Kegiatan guyub sekali seminggu & 10 \\
\hline & & Kegiatan guyub dua kali atau lebih dalam seminggu & 20 \\
\hline & \multirow{3}{*}{$\begin{array}{l}\text { Adanya } \\
\text { kelompok } \\
\text { masyarakat }\end{array}$} & Tidak terdapat kelompok masyarakat & 0 \\
\hline & & Jumlah kelompok masyarakat $1-2$ & 5 \\
\hline & & Jumlah kelompok nelayan lebih dari 2 & 10 \\
\hline & \multirow[t]{3}{*}{ Kepercayaan } & $\begin{array}{l}\text { Tidak ada kepercayaan antar masyarakat sama sekali } \\
\text { (tingkat kepercayaan rendah) }\end{array}$ & $\begin{array}{c}0 \\
10\end{array}$ \\
\hline & & Tingkat kepercayaan masyarakat sedang & 20 \\
\hline & & Tingkat kepercayaan tinggi & \\
\hline & \multirow[t]{3}{*}{ Interaksi } & $\begin{array}{l}\text { Tidak ada interaksi sama sekali antar masyarakat dalam } \\
\text { kurun waktu lingkungan permukiman dalam waktu } \\
\text { seminggu }\end{array}$ & $\begin{array}{c}0 \\
10 \\
20\end{array}$ \\
\hline & & $\begin{array}{l}\text { Lebih dari dua kali interaksi masyarakat dalam kurun } \\
\text { waktu seminggu }\end{array}$ & \\
\hline & & $\begin{array}{l}\text { Lebih dari dua kali interaksi antar masyarakat dalam } \\
\text { kurun waktu seminggu dan memiliki pertemuan } \\
\text { kelompok }\end{array}$ & \\
\hline \multirow[t]{6}{*}{ Psikografi } & \multirow[t]{3}{*}{$\begin{array}{l}\text { Masalah } \\
\text { masyarakat }\end{array}$} & $\begin{array}{l}\text { Tidak memilikimasalah yang menjadi perhatian bersama } \\
\text { masyarakat }\end{array}$ & $\begin{array}{l}0 \\
5\end{array}$ \\
\hline & & $\begin{array}{l}\text { Memiliki 1-2 masalah dalam masyarakat (berupa } \\
\text { kriminalitas, keamanan, pertikaian sosial dan lain- lain) }\end{array}$ & 10 \\
\hline & & $\begin{array}{l}\text { Memiliki lebih dari } 2 \text { masalah yang menjadi perhatian } \\
\text { bersama }\end{array}$ & \\
\hline & \multirow[t]{3}{*}{$\begin{array}{l}\text { Persepsi tentang } \\
\text { hunian }\end{array}$} & $\begin{array}{l}\text { Persepsi masyarakat tentang hunian permukiman } \\
\text { nelayan tidak layak huni }\end{array}$ & $\begin{array}{c}0 \\
10\end{array}$ \\
\hline & & $\begin{array}{l}\text { Persepsi tentang hunian permukiman nelayan memiliki } \\
\text { tingkat layak huni sedang }\end{array}$ & 20 \\
\hline & & $\begin{array}{l}\text { Persepsi tentang hunian permukiman nelayan layak huni } \\
\text { tinggi }\end{array}$ & \\
\hline \multirow[t]{3}{*}{ Partisipasi } & \multirow{3}{*}{$\begin{array}{l}\text { Tingkat } \\
\text { partisipasi } \\
\text { masyarakat }\end{array}$} & Partisipasi sebatas mengikuti sosialisasi & 0 \\
\hline & & Partiispasi ada pada tahap 1-4 tangga partisipasi amstein & 20 \\
\hline & & Partiispasi ada pada tahap 5-8 tangga partisipasi arnstein & 40 \\
\hline \multirow[t]{6}{*}{$\begin{array}{l}\text { Pendekatan } \\
\text { perencanaan }\end{array}$} & \multirow{3}{*}{$\begin{array}{l}\text { Pengawasan } \\
\text { pemerintah dan } \\
\text { Kolaborasi } \\
\text { masyarakat dan } \\
\text { pemerintah }\end{array}$} & $\begin{array}{l}\text { Hanya pemerintah yang ambil alih dalam perencanaan } \\
\text { wilayah penelitian, masyarakat tidak terlibat dalam } \\
\text { pengawasan maupun kolaborasi }\end{array}$ & $\begin{array}{c}0 \\
15 \\
30\end{array}$ \\
\hline & & $\begin{array}{l}\text { Keikutsertaan masyarakat dalam kolaborasi dan } \\
\text { pengawasan terhadap program pembangunan sedang }\end{array}$ & \\
\hline & & $\begin{array}{l}\text { Keikutsertaan masyarakat dalam kolaborasi dan } \\
\text { pengawasan terhadap program pembangunan tinggi } \\
\text { (masyarakat ikut mengawasi kinerja pemerintah dari } \\
\text { awal hingga selesai) }\end{array}$ & \\
\hline & \multirow{3}{*}{$\begin{array}{l}\text { Kemampuan } \\
\text { untuk } \\
\text { menciptakan } \\
\text { ruang kreatif }\end{array}$} & Tidak ada kreativitas menciptakan ruang & 0 \\
\hline & & $\begin{array}{l}\text { Ada kreativitas mencipatakan ruang namun rendah } \\
\text { (menciptakan ruang single use) }\end{array}$ & $\begin{array}{l}15 \\
30\end{array}$ \\
\hline & & $\begin{array}{l}\text { Tingkat menciptakan ruang kreatif tinggi (menciptakan } \\
\text { ruang mix use) }\end{array}$ & \\
\hline
\end{tabular}

Keterangan :

- Nilai bobot 0-66,6 : : tingkat gemeinshcaft city rendah

- Nilai bobot 66,7-133,3 : tingkat gemeinschaft city sedang

- Nilai bobot 113,4-200 : tingkat gemeinschaft city tinggi

Melalui hasil perhitungan tiap variabel di atas maka dapat diketahui total nilai bobot gemeinshcaft city tiap RW RT permukiman nelayan.

\section{IV. HASIL ANALISIS}

\section{A. Deliniasi permukiman nelayan}

Berdasarkan hasil permusan kriteria yang telah dilakukan maka lima variabel yang digunakan untuk menentukan permukiman nelayan ialah kepadatan bangunan, letak permukiman, orientasi kegiatan perairan, aksesibilitas dan kegaitan sosial bersama. Adapun hasil dari pemetaan kelima variabel tersebut adalah sebagai berikut .

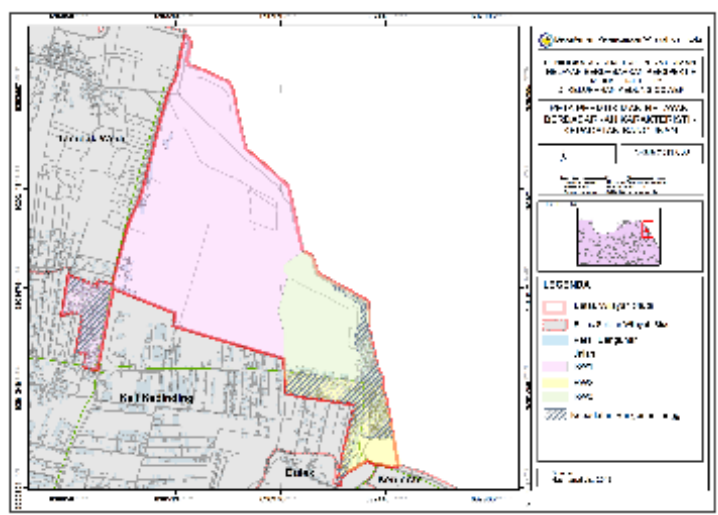

Gambar 1. Kepadatan bangunan

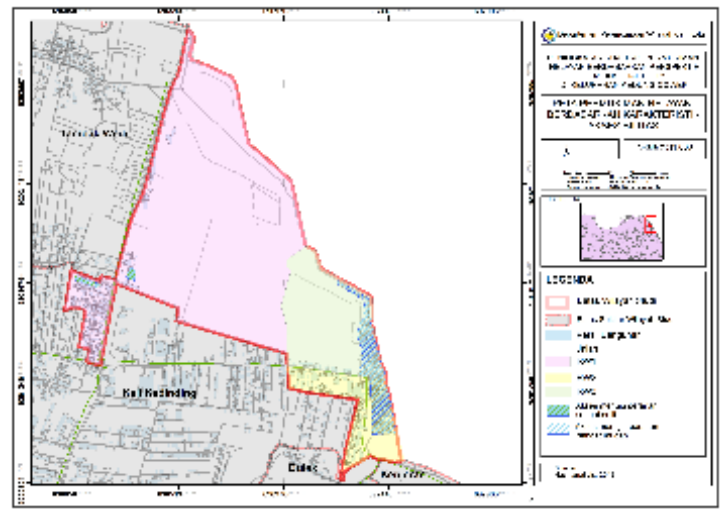

Gambar 2. Aksesibiltas

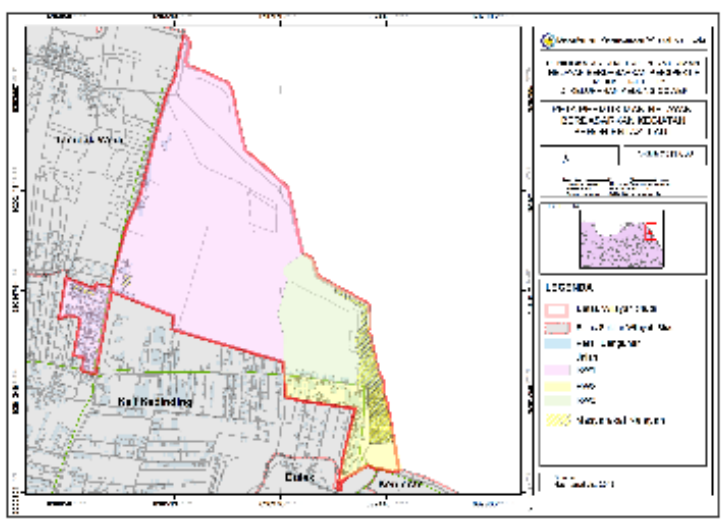

Gambar 3. Kegiatan oritentasi laut/nelayan

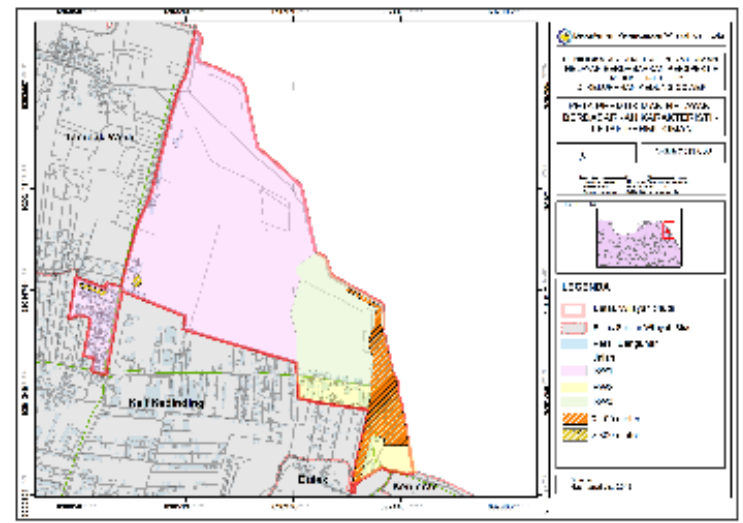

Gambar 4. Letak Permukiman 


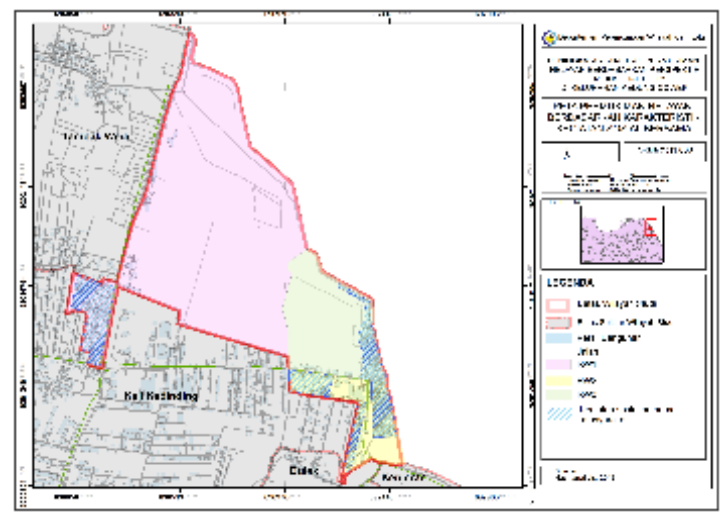

Gambar 5. Kegiatan Sosial

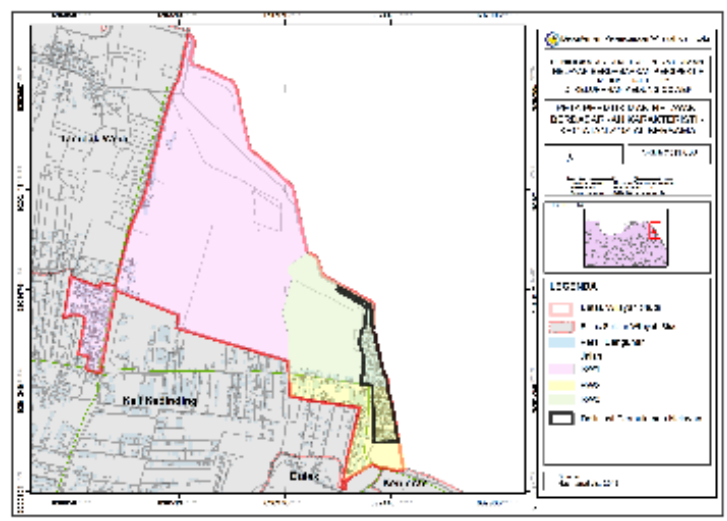

Gambar 5. Hasil deliniasi

Dengan mengaplikasikan kelima variabel tersebut menggunakan software arcgis maka dari itu didapatkan deliniasi permukiman nelayan ialah sebagai berikut. Berdasarkan hasil deliniasi tersebut maka yang termasuk permukiman nelayan di Kelurahan Kedung Cowek ialah RW 2 RT 1, RT 2, RT 3 dan RW 3 RT 1, RT 2 dan RT 3.

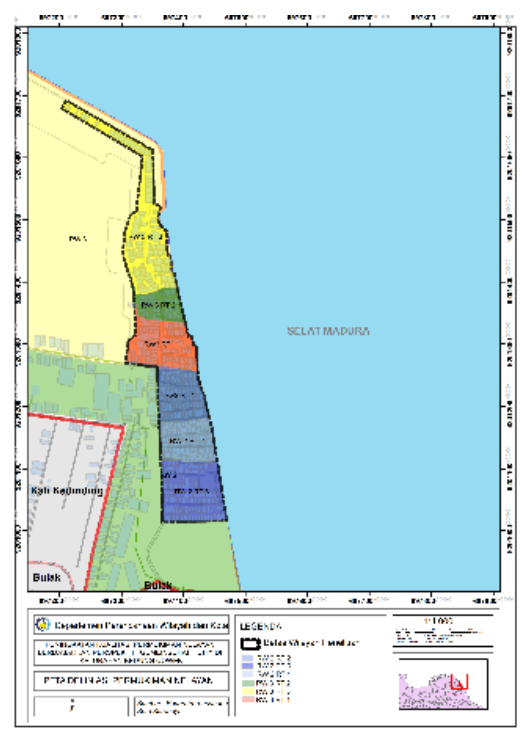

Gambar 6. Deliniasi permukiman Nelayan

\section{B. Tingkat Gemeinshcaft City Permukiman Nelayan}

Dari hasil pembobotan tiap variabel gemeinshcaft city pada masing-masing permukiman nelayan, maka didapatkan hasil sebagai berikut.

Tabel 3.

Tingkat gemeinshcaft city permukiman nelayan

\begin{tabular}{|c|c|c|c|c|c|c|}
\hline \multirow[t]{2}{*}{ VARIABEL } & \multicolumn{6}{|c|}{ SKOR (MEAN) } \\
\hline & RW 2 RT 1 & RW 2 RT 2 & RW 2 RT 3 & RW 3 RT 1 & RW 3 RT 2 & RW 3 RT 3 \\
\hline Aktivitas Guyub & 15,38 & 13,85 & 13,20 & 10,00 & 14,29 & 13,00 \\
\hline $\begin{array}{l}\text { Kelompok } \\
\text { Masyarakat }\end{array}$ & 4,62 & 5,00 & 6,20 & 5,00 & 5,00 & 5,00 \\
\hline Kepercayaan & 20,00 & 14,62 & 18,80 & 17,78 & 11,43 & 18,00 \\
\hline Interaksi & 17,69 & 20,00 & 20,00 & 18,89 & 18,57 & 19,00 \\
\hline $\begin{array}{l}\text { Masalah } \\
\text { masyarakat }\end{array}$ & 3,08 & 3,46 & 2,80 & 3,33 & 2,86 & 2,50 \\
\hline $\begin{array}{l}\text { Persepsi tentang } \\
\text { hunian }\end{array}$ & 9,23 & 17,69 & 15,20 & 15,56 & 15,71 & 14,00 \\
\hline $\begin{array}{l}\text { Tingkat } \\
\text { Partisipasi } \\
\text { masyarakat }\end{array}$ & 36,92 & 29,23 & 25,60 & 26,67 & 28,57 & 36,00 \\
\hline $\begin{array}{l}\text { Pengawasan dan } \\
\text { kolaborasi }\end{array}$ & 25,38 & 18,46 & 16,20 & 23,33 & 21,43 & 25,50 \\
\hline $\begin{array}{l}\text { Kemampuan } \\
\text { menciptakan } \\
\text { ruang }\end{array}$ & 18,46 & 17,31 & 14,40 & 18,33 & 21,43 & 18,00 \\
\hline Total & 150,77 & 139,62 & 132,40 & 138,89 & 139,29 & 151,00 \\
\hline Tipologi & $\begin{array}{l}\text { gemeinshaft } \\
\text { city tinggi }\end{array}$ & $\begin{array}{l}\text { gemeinshaft } \\
\text { city tinggi }\end{array}$ & $\begin{array}{l}\text { gemeinshafft } \\
\text { city sedang }\end{array}$ & $\begin{array}{l}\text { gemeinshafft } \\
\text { city tinggi }\end{array}$ & $\begin{array}{l}\text { gemeinshaft } \\
\text { city tinggi }\end{array}$ & $\begin{array}{l}\text { gemeinshaft } \\
\text { city tinggi }\end{array}$ \\
\hline
\end{tabular}

Visualisasi dari tingkat gemeinshcaft city dapat dilihat pada grafik dibawah ini

RW 2 RT 1

RW 2 RT 2
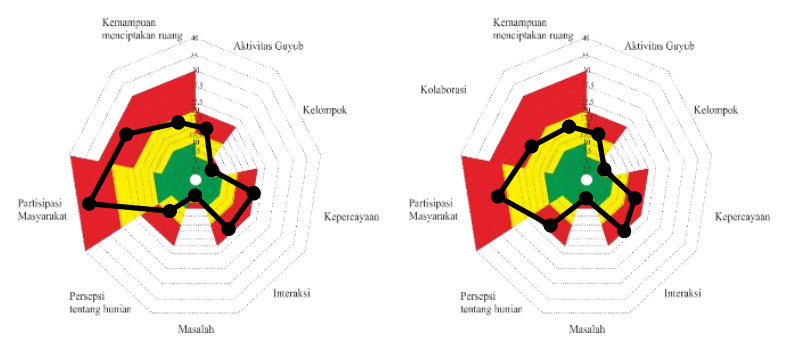

RW 2 RT 3
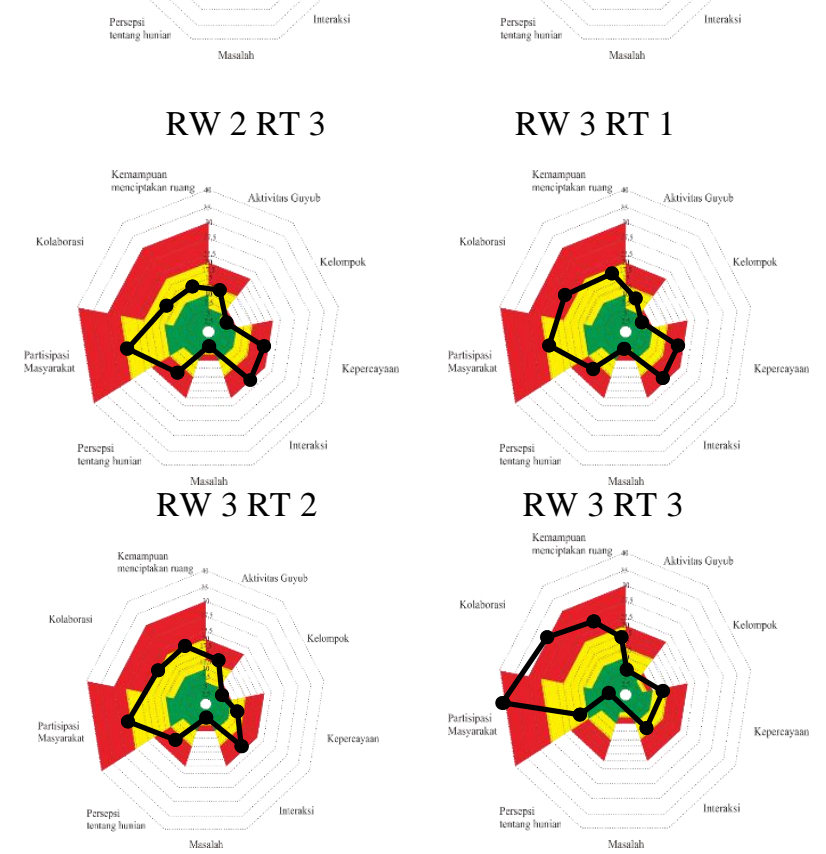

Gambar 7. Diagram radar gemeinshcaft city permukiman nelayan

Berdasarkan hasil keseluruhan indikator gemeinshcaft citydapat disimpulkan didapatkan hasil bahwa semua permukiman nelayan beraada pada kategori tingkat gemeinshcaft city tinggi, namun terdapat satu permukiman 
yang merupakan tingkat gmeinshcaft city sedang yakni di RW 3 RT 2.

Pada masing-masing variabel, variabel tingkat partisipasi memiliki bobot yang paling tinggi diantara variabel lainnya. Permukiman yang memiliki nilai variabel partisipasi paling tinggi ialah RW 2 RT 1. Variabel aktivitas guyub, tiga permukiman pada kategori tinggi yakni RW 2 RT 1, RW2 RT3, RW3 RT 2, sedangkan lainnya termasuk pada kategori sedang. Sementara variabel kelompok masyarakat semua permukiman berada pada kategori sedang yakni memiliki 1-2 kelompok yang memiki kelompok nelayan lebih dari 2 kelompok adalah RW 2 RT 3. Variabel kepercayaan, semua masyarakat di permukiman nelayan memiliki tingkat kepercayaan yang tinggi antar sesama masyarakat kecuali permukiman RW 3 RT 2. Selanjutnya variabel interaksi, semua permukiman berada pada kategori tinggi.

Sementrara untuk variabel masalah dan persepsi tentan hunian, kedua variabel ini berada pada kategori sedang. Variabel kolaborasi di permukiman nelayan didominasi oleh kolaborasi kategori tinggi kecuali RW 2 RT 2 dan RW 2 RT 3 yang berada pada kategori sedang. Sementara untuk variabel kemampuan menciptakan ruang, rata-rata masyarakat memiliki kemampuan menciptakan raung pada kategori sedang, kecuali RW 3 RT 2.

Variabel yang keseluruhan lingkungan permukiman termasuk dalam kategori sedang ialah kelompok masyarakat. Hal ini dikarenakan masih minimnya jumlah kelompok di lingkungan permukiman dan homogen. Sementara variabel yang masuk dalam kategori rendah ialah variabel masalah, terdapat tiga lingkungan permukiman masuk dalam kategori rendah dan tiga lainnya masuk kategori sedang, hal ini mengindikasikan bahwa masih terdapatnya sejumlah masalah yang menjadi perhatian bersama di kalangan masyarakat nelayan.

Pembangunan Taman Suroboyo ini berimbas pada pembangunan permukiman nelayan warna-warni dimana program tersebut dirasakan langsung oleh RW 2 RT 3. Sejak permukiman di wilayah ini mendapat bedah rumah dan perbaikan tempat penjemuran oleh pemerintah yang disertai sosialisasi permukiman membuat persepsi masyarakat nelayan terhadap hunian semakin tinggi. Para nelayan semakin menyadari bahwa permukiman yang mereka tinggali masih kurang layak huni untuk bisa mendukung wisata kampung nelayan. Hal inilah yang membuat $72 \%$ dari sampel survey menyatakan bahwa permukiman wilayah tersebut masih kurang layak huni, sehingga masih membutuhkan bantuan pemerintah seperti bedah rumah. Hal lain yang membuat RW 2 RT 3 masuk dalam kategori sedang ialah kolaborasi dan tingkat partisipasi masyarakat. $72 \%$ sampel survey mengakui bahwa tingkat partisipasi masyarakat hanya sebatas pada medengarkan informasi, penyebaran informasi dan mulai tertarik untuk berdiskusi dan berpartisipasi. Namun kenyataannya, saat diajak berpartisipasi dalam program pemerintah, masyarakat nelayan tidak berpartisipasi aktif karena mereka menganggap bahwa program tersebut hanya tanggung jawab pemerintah.

\section{IV. KESIMPULAN}

Variabel yang digunakan untuk merumuskan permukiman nelayan di Kelurahan Kedung Cowek antara lain kepadatan bangunan, letak permukiman, kegiatan sosial bersama, kegiatan beroritentasi laut, dan aksesibilitas

Daerah permukiman yang termasuk permukiman nelayan ialah RW 2 RT 1, RT 2, RT 3 dan RW 3 RT 1, RT 2, RT 3.

Berdasarkan hasil skoring yang dilakukan diketauhi perbedaan tingkat gemeinschaft city permukiman nelayan. Permukiman dengan tngkat gemeinshcaft city tinggi ialah ialah RW 2 RT 1, RT 2 dan RW 3 RT 1, RT 2, RT 3. Sedangkan permukiman dengan tingkat gemeinshcaft city sedang berada pada permukiman RW 2 RT 3

Adanya perbedaan tingkat gemeinshcaft city disebabkan perbedaan bobot variabel dan kondisi eksisting dari kekerabatan masyarakat nelayan

\section{DAFTAR PUSTAKA}

[1] Kementerian Pekerjaan Umum dan Perumahan Rakyat, Direktorat Jenderal Cipta Karya. Kota Tanpa Kumuh 2016.

[2] Dokumen Rencana Detail Tata Ruang Kota (RDTRK) UP Tambak Wedi 2008

[3] Hadi, R.A. dan Umilia, E. 2018. Bentuk Partisipasi Masyarakat Dalam Program PLP-BK Di Kelurahan Kedung Cowek. Surabaya: Institut Teknologi Sepuluh Nopember. Jurnal Teknik ITS, 7(1), pp.44-46.

[4] Lailiyah, Fatihatul. 2014. Implementasi Pembangunan Partisipatif Pada Program GPO-BA di Kota Surabaya. Surabaya: Universitas Airlangga

[5] Baga, Veronika Diaz. 2017. Faktor - Faktor yang Mempengaruhi Eksistensi Nelayan Tradisionela Di Kelurahan Kedung Cowek Kecamatan Bulak Kota Surabaya. Surabaya: Universitas Negeri Surabaya. Swara Bhumi. Volume IV Nomor 4, 2017: 91-99.

[6] Pradinie, Karin. 2018. Gemeinshcaft City : Konsep dan Pengukuran Kota Guyub. Surabaya: Institut Teknologi Sepuluh Nopember. Jurnal Penataan Ruang Volume 13 iSSN 1907-4972.

[7] Budiharjo, Eko. 1984. Sejumlah Masalah Permukiman Kota. Bandung: Alumni.

[8] Suprihardjo, R. dan Dian Rahmawati. 2014. Peran Masyarakat dan Permukiman Nelayan Sebagai Dasar Pengembangan Kawasan Minapolitan Di Lamongan, Studi Kasus Permukiman Minapolis Brondong Lamongan (The Role Of Community And Fishing Settlement As A Basis For The Development Of The Minapolitan Area). Tesa Arsitektur, Journal Of Architectural Discourses, 12(2), P.129.

[9] Suprihardjo, R. dan Dian Rahmawati. 2017. Identifikasi Pola Perkembangan Permukiman Pesisir Melalui Pendekatan Ekistic Studi Kasus: Wilayah Pesisir Brondong-Paciran Lamongan. Surabaya: Institut Teknologi Sepuluh Nopember. Jurnal Penataan Ruang, Vol. 9, No. 1, Mei 2014.

[10] Tonnies, Ferdinand. 1889. Gemeinschaft and Gessellschaft. Harvard Collage Library.

[11] Supriharjo, Rimadewi, dkk. 2013. Diktat Metodologi Penelitian. Surabaya: Institut Teknologi Sepuluh Nopember.

[12] Kuswartojo, Tjuk. dkk. 2005. Perumahan dan Permukiman di Indonesia: Upaya Membuat Perkembangan Kehidupan yang Berkelanjutan. Bandung: ITB.

[13] Ramdani, Bani Dipra dan Ragil Haryanto, 2013. Presepsi Masyarakat terhadap Penataan Kawasan Permukiman Nelayan Kumuh di Desa Kurau, Kecamatan Koba, Kabupaten Tengah. Semarang: Universitas Diponegoro. 
[14] Surtiani, 2006. Faktor-Faktor yang Mempengaruhi Terciptanya Kawasan Permukiman Kumuh di Kawasan Pusat Kota (Studi Kasus: Kawasan Pancuran, Salatiga). Semarang: Universitas Diponegoro Semarang. 